\title{
ANALISIS KONSEP GREEN ROOF PADA KAMPUS SCHOOL OF ART, DESIGN AND MEDIA NTU SINGAPORE DAN PERPUSTAKAAN UI DEPOK
}

\author{
Ratna Dewi Nur'aini \\ Pogram Studi Arsitektur, FakultasTeknik, UniversitasMuhammadiyah Jakarta \\ Jl. CempakaPutih Tengah 27 Jakarta Pusat, 10510 \\ ratnadewina@ftumj.ac.id; ratnadewina@gmail.com
}

\begin{abstract}
ABSTRAK. Jakarta termasuk salahsatu kota yang terletak di daerahberiklim tropis. Sebagai ibukota negara, Jakarta mempunyai kepadatan penduduk sangat tinggi, lahan terbuka hijau semakin berkurang. Banyak sekali ditemukan bangunan yang menggunakan Air Conditioning (AC) sehingga akan menimbulkan global warming. Bangunan pendidikan merupakan salah satu bangunan yang perlu didesain sedemikian rupa sehingga menjadi nyaman dan tidak merusak lingkungan, yang akan mendukung terciptanya sumber daya manusia yang berkualitas. Perlu adanya kajian konsep green building pada bangunan-bangunan yang mempunyai fungsi pendidikan di daerah iklim tropis untuk menjadi sumber referensi yang nantinya bisa diterapkan di kota Jakarta pada khususnya. Pada penelitian ini kajian green building difokuskan pada analisis tentang green roof pada bangunan pendidikan. Tujuan dari penelitian ini adalah mengidentifikasi konsep green roof bangunan kampus School of Art, Design and Media NTU Singapore dan bangunan Perpustakaan UI Depok dan menganalisisnya untuk dapat diterapkan di Kota Jakarta pada khususnya. Metode yang digunakan dalam penelitian ini adalah deskriptif kualitatif. Lokasi penelitian ini adalah kampus Nanyang Technological University School of Art, Design and Media SingapuradanGedungPerpustakaan Universitas Indonesia Depok yang menggunakan aplikasi green roof. Hasil penelitian ini menunjukkanbahwa sistem berkelanjutan telah menjadi salah satu kebijakan prioritas di kota Singapura dan Jakarta. Green roof tidak hanya merupakan upaya untuk menciptakan arsitektur berkelanjutan, tetapi juga dari segi estetika. Green roof merupakan salah satu aplikasi konsep green building yang tepat untuk diaplikasikan pada bangunan-bangunan pendidikan yang ada di Jakarta sebagai kota yang memiliki kepadatan bangunan tinggi dan lahan terbuka hijau yang sangat terbatas.
\end{abstract}

Kata kunci:bangunan pendidikan, greenroof, iklim tropis, Kampus NTU, Perpustakaan UI Depok

ABSTRACT. Jakarta is located in tropical climate. As the capital city, Jakarta has been regarded as a city with high population, and has limited green open space. Many people have used Air Conditioning (AC) to make their living comfortable, and that has caused global warming. Education building is one of the buildings that needed comfortable design that should consider environmental friendly, and will support human resources quality. Green building concept is needed for education buildings in tropical climate as references that can be applied in Jakarta. In this research, study of green building focused on the analysis of green roof in educational buildings. The objective of this research is to identify green roof concept in School of Art, Design and Media Singapore and library of UI Depok and to analyze them to be applied in Jakarta. The research method is descriptive qualitative. Locations of this research are campus of Nanyang Technological University (NTU) School of Art, Design and Media of Singapore and Library Building of Universitas Indonesia (UI) Depok which used green roof application. The result of this research indicated that sustainable systems became one of the priority policies in Singapore and Jakarta. Green roof can create sustainable architecture and aesthetics. Green roof is one application of green building concept that can be applied on education buildings in Jakarta that has high density of buildings and limited green open space.

Keywords: education building, green roof, tropical climate, NTU campus, library of UI Depok

\section{PENDAHULUAN}

Indonesia termasuk salah satu negara yang beriklimtropis yang berada di daerah katulistiwa. Kota Jakarta sebagai ibukota Negara mempunyai kepadatan penduduk yang sangat tinggi, lahan terbuka hijau semakin berkurang. Banyak sekali ditemukan bangunan-bangunan yang menggunakanAir Conditioning (AC) untuk menciptakan kenyamanan penghuninya. Namun sebenarnya penggunaan $A C$ tersebut justru menjadi salahsatu penyebab global warming. Fenomena ini menjadi salah satu permasalahan yang perlu diperhatikan oleh peneliti untuk menemukan solusi yang tepat.

Bangunan pendidikan yang berfungsi sebagai tempat belajar/kuliah merupakan salah satu fasilitas kota yang perlu didesain sedemikian 
rupa sehingga pelajar/mahasiswa sebagai pengguna utama bangunan tersebut akan merasa nyaman melakukan proses belajar mengajar dengan desain yang tidak merusak lingkungan, akan sangat mendukung terciptanya sumber daya manusia yang berkualitas.Salah satu alternatif desain yang bisa diterapkan untuk memberikan kenyamanan bagi para pengguna bangunan adalah konsep green building.

Konsep green mulai muncul di Indonesia baru beberapa tahun belakangan ini. Konsep green sebenarnya merupakan turunan dari prinsip sustainability (keberlanjutan), yaitu kemampuan berbagai macam sumber daya di bumi ini berinteraksi dengan sistem budaya manusia dan ekonomi serta daya adaptasinya dalam menghadapi kondisi lingkungan yang pastinya terus berubah [1].

Menurut Salim [2], sustainabilitas pembangunan memerlukan sinergi antara modal manusia, modal sosial, modal fisik, modal keuangan dan modal alam. Modal manusia yaitu kualitas jasmani dan rohani, modal sosial meliputi sipil dan pemerintah yaitu berwujud interaksi tingkat mikro dan tingkat makro, modal fisik yaitu buatan manusia, pabrik, jalan, dan lain-lain, modal keuangan yaitu sarana perbankan asuransi.

Implementasi konsep green building merupakan salah satu penerapan dari konsep sustainabilitas, dimana dalam membangun harus memperhatikan sinergi modal manusia,modal sosial, modal fisik, modal keuangan dan modal alam. Karena itu dalam menerapkan konsep green building banyak sekali faktor yang diperhatikan, lingkungan hidup natural, keberlangsungan manusia sebagai individu, anggota masyarakat serta norma budaya yang dianut. Diharapkan dengan diterapkannya konsep green building dapat memacu para arsitek untuk meningkatkan kinerja, keilmuan dan keprofesionalan dalam berkarya.

Menurut Pimpinan Center for Building Energy Study Universitas Petra, Surabaya, Ir Jimmy Priatman, M Arch, green building tidak bisa dipisahkan dari green architecture. Green building tidak hanya hemat energi tapi juga hemat air, melestarikan sumber daya alam, dan meningkatkan kualitas udara. Sementara green architecture adalah bagaimana mengubah empat hal itu menjadi bagian yang berkesinambungan[3].
Indonesia memiliki lembaga yang bertujuan untuk menciptakan lingkungan yang lebih sehat. Lembaga tersebut bernama Green Building Council Indonesia (GBCl). GBCl terdiri dari beberapa profesional di bidangnya, seperti: konstruksi, industri bangunan dan properti, pemerintah, akademisi, dan komunitas yang memiliki kepedulian terhadap lingkungan.

GBCl mempunyai salah satu program greenship yaitu sebuah perangkat penilaian yang disusun untuk menentukan apakah suatu bangunan dapat dinyatakan layak bersertifikat "bangunan hijau" atau belum. Penyusunan greenship ini didukung oleh World Green Building Council, dan dilaksanakan oleh Komisi Rating dari GBCl. Sistem ratinggreenship berisi butir-butir dari aspek penilaian. Setiap butir rating mempunyai nilai (credit point). Apabila suatu bangunan berhasil melaksanakan butir rating, maka bangunan itu akan mendapatkan poin nilai dari butir tersebut. Bila jumlah semua poin nilai yang berhasil dikumpulkan mencapai suatu jumlah yang ditentukan, maka bangunan tersebut dapat disertifikasi untuk tingkat sertifikasi tententu.

Secara umum, greenship memiliki enam aspek penilaian, yaitu [4]:

1) Tepat Guna Lahan (Appropriate Site Development/ASD)

2) Efisiensi Energi \& Refrigeran (Energy Efficiency \& Refrigerant/EER)

3) Konservasi Air (Water Conservation/WAC)

4) Sumber \& Siklus Material (Material Resources \& Cycle/MRC)

5) Kualitas Udara \& Kenyamanan Udara(Indoor Air Health \& Comfort/IHC)

6) Manajemen Lingkungan Bangunan (Building \&Enviroment Management)

Salah satu penerapan aspek efisiensi energy dalam green building adalah aplikasi green roof pada bangunan.

Green roof merupakan konstruksi atap yang menggunakan material tanaman. Penerapan green roof pada suatu bangunan mempunyai beberapa manfaat, antara lain [5]:

1) Menciptakan pemandangan kota yang indah dan nyaman.

2) Mengurangi polusi udara dan membuat kota lebih sehat. Tanaman mampu mengurangi polusi udara hingga $0.5 \mathrm{~kg}$ per tahun. 
3) Menciptakan living space dan tempat rekreasi bagi masyarakat.

4) Menciptakan ruang untuk istirahat dan relax.

5) Meningkatkan kualitas air dan udara.

6) Menciptakan bangunan ekologi.

7) Mengurangi biaya pemeliharaan atap.

8) Menciptakan daerah hijau.

9) Meningkatkan kualitas hidup.

10) Mencegah radiasi ultraviolet dan perubahan suhu secara ekstrim di sekitar bangunan.

11) Meningkatkan system drainase kota.

12) Meredam kebisingan dan menyimpan energi panas.

Sedangkan menurut Skyscape [6], green roof memberikan manfaat yang sangat banyak bagi lingkungan, antara lain:

1) Terbuat dari beberapa lapisan sehingga atap dapat mengurangi panas, dan mengurangi biaya untuk pendinginan $(A C)$.

2) Melindungi material atap dari sinar Ultra Violet dan tekanan suhu panas.

3) Meringankan beban waterproofing akibat tekanan angin.

4) Menambah panjang usia system atap.

5) Meningkatkan area resapan air hujan.

6) Meningkatkan kualitas udara yang dihasilkan dari konversi karbondioksida $\left(\mathrm{CO}_{2}\right)$ menjadi oksigen $\left(\mathrm{O}_{2}\right)$ dan penurunan suhu udara ambien, sehingga mengurangi efek rumah kaca.

7) Meningkatkan estetika.

8) Menciptakan habitat satwa liar.

9) Memberikan kontribusi nyata bagi program green building projects.

Green roof dapat diaplikasikan pada atap datar ataupun miring. Secara umum lapisan green roof terdiri dari konstruksi atap, membran waterproofing, drainase, media tanam dengan tebal hingga mencapai 2 meter, dan tanaman. Tanah yang digunakan biasanya memiliki komposisi butir-butir tanah liat yang ringan dan batu pecah. Jenis tanaman tidak hanya sebatas tanaman perdu, tetapi juga pohon besar sehingga mampu menghadirkan satu kesatuan ekosistem [7]. Jenis tanaman disesuaikan dengan kondisi cuaca dan iklim setempat. Tanaman yang tahan dengan cuaca kering lebih cocok dipilih guna lebih menghemat biaya pengairan, walaupun sistem pengairan tetap diperlukan.

Walaupun pengerjaan green roof lebih mahal daripada atap konvensional, namun memiliki nilai efektif lebih lama. Green roof dapat menghemat energi dan mampu melindungi properti di bawahnya, misalnya tanaman dan tanah melindungi membran waterproof dari kerusakan akibat radiasi ultraviolet matahari, mampu memperpanjang fungsinya hingga lebih dari 20 tahun. Dalam suatu penelitian, green roof di Berlin telah bertahan 90 tahun tanpa perbaikan yang signifikan.

Tujuan dari penelitian ini adalah mengidentifikasi konsep green roof bangunan kampus School of Art, Design and Media NTU Singapore dan bangunan Perpustakaan UI Depok dan menganalisisnya untuk dapat diterapkan di Kota Jakarta pada khususnya.

Hasil penelitian ini diharapkan dapat memperkaya perbendaharaan ilmu arsitektur terutama mengenai green building sehingga dapat dijadikan pertimbangan terhadap desain bangunan pendidikan yang dapat mendukung proses belajar mengajar.

\section{METODE PENELITIAN}

Penelitian ini secara umum merupakan penelitian deskriptif kualitatif. Metode deskriptif digunakan untuk mendeskripsikan, mengidentifikasi, dan menganalisis konsep green building yang ditemukan pada bangunan pendidikan di daerah beriklim tropis.

Objek penelitian ini mengambil studi kasus bangunan dengan fungsi pendidikan di daerah iklim tropis yang desainnya berkonsep green building. Bangunan yang diamati sebagai objek penelitian adalah Kampus Nanyang Technological University (NTU) School of Art, Design and Media (ADM) di Singapura dan Gedung Perpustakaan Universitas Indonesia (UI) Depok.

Persiapan awal dilakukan dengan pengamatan beberapa bangunan yang akan diteliti dengan mencari data-data sekunder dan informasi, serta mengkaji beberapa literatur terkait tentang green building.

Teknik pengumpulan data pada objek penelitian dengan cara observasi dan análisis dokumen. Penelitian dilakukan dengan observasi ke Kampus Nanyang Technological University (NTU) School of Art, Design and Media (ADM) di Singapura dan Gedung Perpustakaan Universitas Indonesia (UI) Depok. Dalam observasi tersebut mengamati dan mengidentifikasi unsur-unsur konsep greenbuilding pada kedua bangunan tersebut (interior dan eksterior). Selain itu 
menggunakan cara studi literatur tentang aplikasi green building khususnya greenroof pada kedua bangunan tersebut, mencari informasi melalui internet, jurnal, laporan penelitian dan pustaka lainnya.

Semua data yang telah didapatkan pada masing-masing bangunan kemudian diidentifikasi unsur-unsur green building dengan menggunakan parameter rating greenship dari $\mathrm{GBCl}$. Setelah masing-masing bangunan teridentifikasi konsep green building, kemudian dirumuskan konsep greenbuilding secara umum pada bangunanbangunan tersebut. Konsep greenbuilding tersebut dianalisis kemungkinan diterapkan pada banngunan pendidikan di Indonesia khususnya di kota Jakarta sebagai kota yang memiliki kepadatan penduduk yang sangat tingi dan kota yang memiliki keterbatasan lahan.

\section{HASIL DAN PEMBAHASAN}

Beberapa bangunan dengan fungsi pendidikan yang menerapkan konsep greenbuilding antara lain:

\section{KampusNanyang Technological University (NTU) School of Art, Design and Media, Singapura}

Nanyang Technological University (NTU) sebagai salah satu universitas terkemuka di dunia memiliki lahan 200 hektar, terletak di pinggiran barat daya Singapura. Bangunan School of Art, Desain and Media (ADM) adalah sekolah seni profesional yang pertama di Singapura yang luasan lahannya sekitar 1 hektar. Hoong Bee LokdariCPG Consultants Pte Ltd, arsitek bangunan ini menyatakan bahwa lokasi dari bangunan ini adalah hutan. Desain bangunan ini tetap mempertahankan konsep green yang menyatu dengan lanskapnya, perpaduan yang harmonis antara material kaca dan rumput. Desain bangunan ini terdiri dari empat lantai dengan mengaplikasikan green roof yang mempunyai sudut kemiringan hampir $45^{\circ}$. Dibentuk oleh dua busur miring, meruncing yang saling mengunci dengan konstruksi atap beton bertulang.

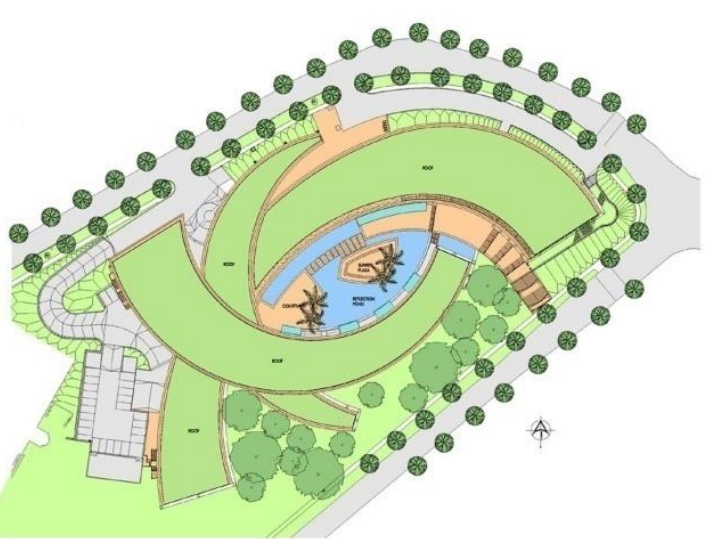

Gambar 1. Block plan Kampus NTU School of Art, Design and Media[8]

Halaman dibentuk oleh ruang di antara dua bangunan dengan interior indah dengan fasad kaca mengkilap. Ditengahnya ada air mancur dan kolam yang mencerminkan suasana komunal dan terkesan mendinginkan ruang. Pada malam hari, bangunan menyala dari pencahayaan interior terlihat melalui dinding kaca, sehingga bangunan ini terkesan seperti permata di dalamhutan.

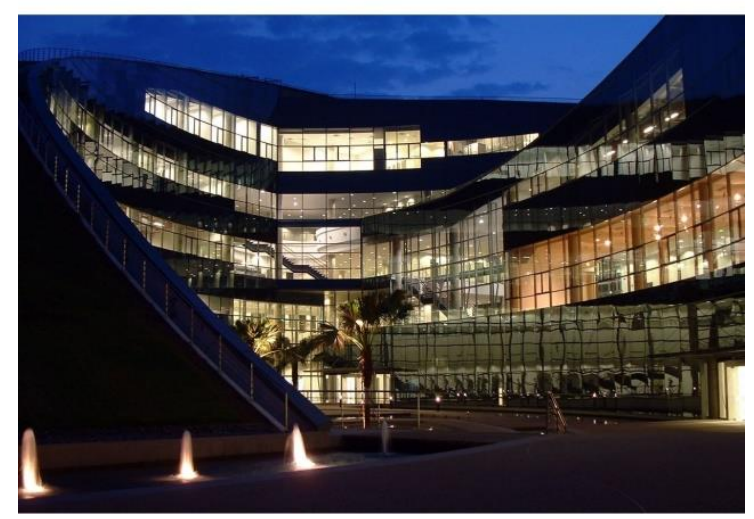

Gambar 2.Fasad Kampus NTU School of Art, Design and Media[8]

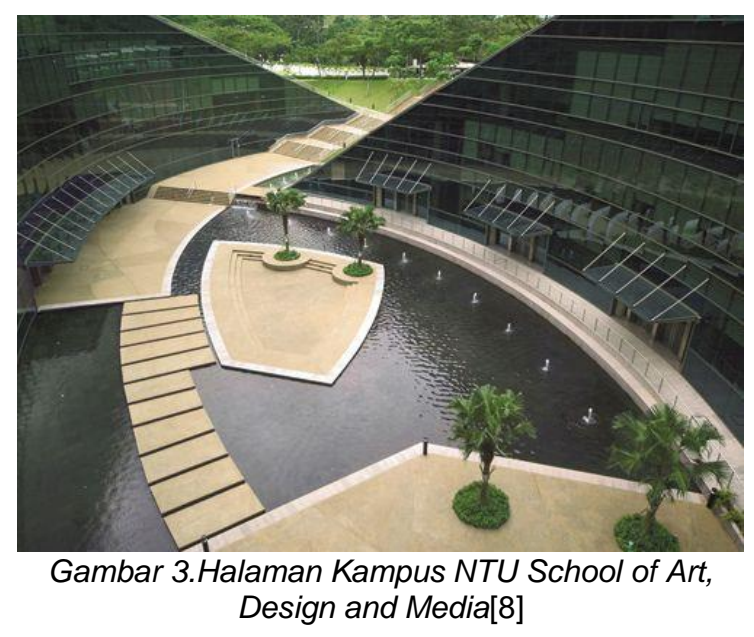


Selain menjadi fitur estetika yang berfungsi sebagai ruang komunal,green roof menjaga suhu ambien rendah dan mengurangi panas di siang hari. Selain itu, kolam di halaman tengah memberikan visual yang menarik terlihat dari ruang kelas, laboratorium dan kantor yang berada pada bangunan di sekelilingnya. Beberapa fasilitas media yang ada pada bangunan ini adalah laboratorium digital dan fotografi, film animasi dan studio. Fasilitas perpustakaan yang lengkap dan auditorium yang dapat menampung kursi 445 orang.

Atap green roof terdiri dari kombinasi dari dua rumput yaitu Zoysia Matrella dan Ophiopogon. Ketebalan lapisan dari green roof sekitar $15 \mathrm{~cm}$. Atap melengkung dapat diakses oleh tangga di sepanjang tepinya. Di bawah atap rumput empat lapisan material meliputi batuan vulkanik, batu apung dan pasir (untuk akar rumput). Penyiraman dengan sistem sprinkler otomatis dari air hujan. Fungsi atap green roof sebagai ruang terbuka, melindungi bangunan, mendinginkan udara dan menyerap air hujan untuk irigasi lansekap. Hal ini sangat bermanfaat sekali untuk mereduksi udara panas di Singapura yang terletak didaerah iklim tropis. Sensor hujan dipasang untuk mengotomatisasi proses irigasi sehingga irigasi akan berhenti saat hujan. Selain mempunyai daya tarik secara visual, juga menciptakan ruang komunal bagi mahasiswa untuk berinteraksi.

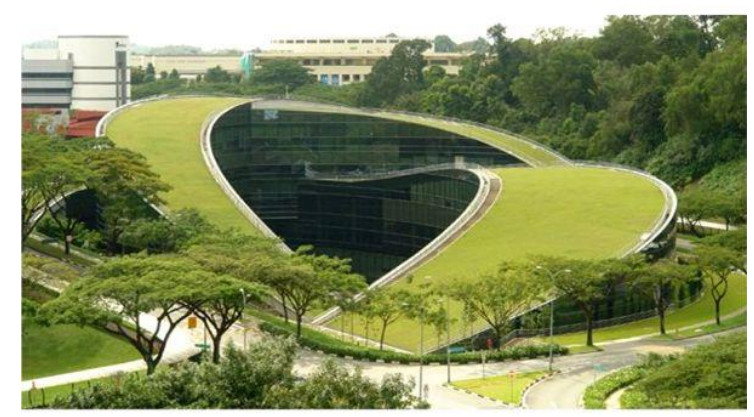

Gambar 4.Aplikasi Green Roof padaKampus NTU School of Art, Design and Media[8]

Nanyang Technological University (NTU) menerima the Green Mark Platinum Awarddari the Singapore Building and Construction Authority (BCA) dalam kelestarian lingkunganpadabulan Mei 2011. Penghematan energi hampir $120.000 \mathrm{kWh}$ per tahun dan lebih dari 1.170 meter kubik air yang disimpan per tahun, sehingga bisa menurunkan biaya operasional dan pemeliharaan. Hemat energi dan efisiensi air, efisiensi lampu dengan sensor gerak dan panel surya, sensor air hujan untuk irigasi. Penggunaan sensor karbon dioksida untuk mengurangi energi yang digunakan dan menjaga kualitas udara dalam ruangan yang sehat.

\section{Gedung Perpustakaan Universitas Indonesia, Depok}

Perpustakaan Universitas Indonesia yang terletak di Kota Depok merupakan salah satu contoh bangunan yang menggunakan atap green roof, sebagai pusat dimana ilmu pengetahuan tersimpan disana. Penerapan green roof pada Perpustakaan UI ini bertujuan untuk memberikan kenyamanan kepada para mahasiswa maupun para pengunjung perpustakaan disaat belajar maupun membaca buku. Green roof merupakan sebuah konsep arsitektur yang berusaha meminimalkan pengaruh buruk terhadap alam maupun manusia. Konsep ini sangat bertanggung jawab terhadap lingkungan dengan cara memanfaatkan sumber energi dan sumber daya alam secara efisien dan optimal. Serta tetap konsisten terhadap konsepnya menyatu dengan alam tanpa merusak alam sekitarnya. Selain itu green roof juga mengurangi pemanasan dengan menambahkan massa dan nilai resistensi termal serta mampu mengurangi hilangnya panas dan konsumsi energi pada musim dingin, dengan mengurangi pendinginan hingga $50-90 \%$ [9].

Perpustakaan Pusat Universitas Indonesia merupakan perpustakaan terbesar di Asia Tenggara ini memiliki desain arsitektur yang diilhami dari potongan batuan kristal, sesuai dengan slogannya "Crystal of Knowledge". Desain gedung perpustakaan ini dipilih melalui kompetisi desain terbuka.

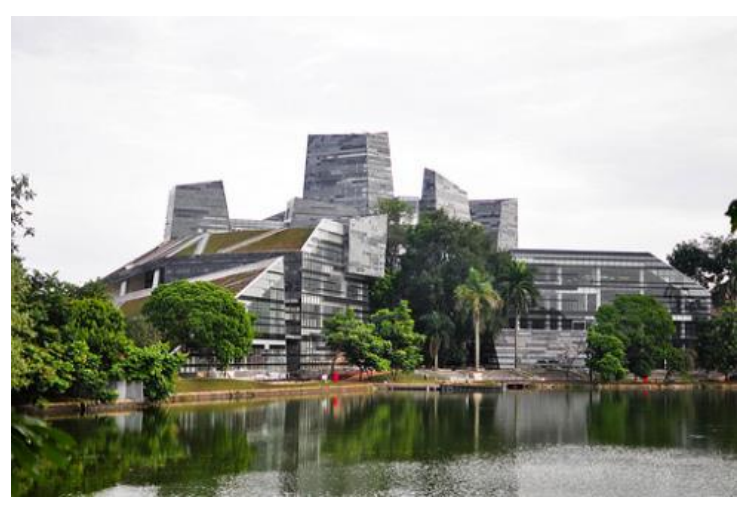

Gambar 5. Tampak depan perpustakaan UI [10]

Perpustakaan pusat UI ini terletak di dekat danau, yang menyajikan pemandangan yang indah dan tenang. Luas bangunan sekitar $3 \mathrm{Ha}$ yang terdiri dari 8 lantai. Sebagian besar 
bangunan menggunakan batu granit berwarna hitam dan abu-abu. Pada bagian atap bangunan menggunakan konsep green roof yang berfungsi meredam udara panas yang ada di dalam ruang, sehingga mengurangi beban penggunaan AC. Pada beberapa ruang memanfaatkan skylight untuk menerangi ruangan yang ada di dalamnya. Pada bagian pintu masuk ruang buku dan ruang baca, dihiasi dengan berbagai alfabet asing yang dicetak timbul.

Bangunan ini mempunyai konsep sustanable building yang ramah lingkungan (eco friendly), kebutuhan energi menggunakan sumber energi terbarukan, yakni energi matahari (solar energy), di dalam gedung tidak diperbolehkan menggunakan plastik dalam bentuk apapun. Kebutuhan plastik akan diganti dengan kertas atau bahan lain. Bangunan ini juga didesain bebas asap rokok, hemat listrik, air dan kertas.

Perpustakaan ini mampu menampung sekitar 10.000 orang pengunjung dalam waktu bersamaan atau sekitar 20.000 orang perhari. Koleksi buku terdiri dari 3-5 juta judul buku. Sistem IT mutakhir juga melengkapi perpustakaan tersebut sehingga pengunjung akan leluasa menikmati sumber informasi elektronik seperti e-book, e-journal dan lainlain.

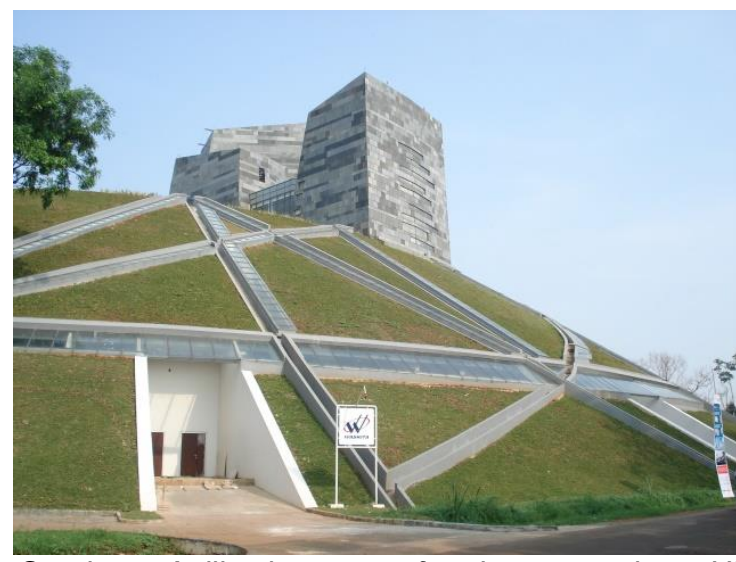

Gambar 6.Aplikasi green roof pada perpustakaan UI [10]

Desain bangunan Perpustakaan UI menghadirkan bangunan masa depan dengan mengambil sisi danau sebagai orientasi perancangan.

Penggunaan bukit buatan sebagai potensi pemanfaatan atap dimaksudkan untuk fungsi penghijauan. Pencahayaan alami diperoleh melalui beberapa skylight. Di balik rerumputan hijau terdapat 5 bangunan tinggi yang menjulang tinggi sebagai ruang utama perpustakaan UI.

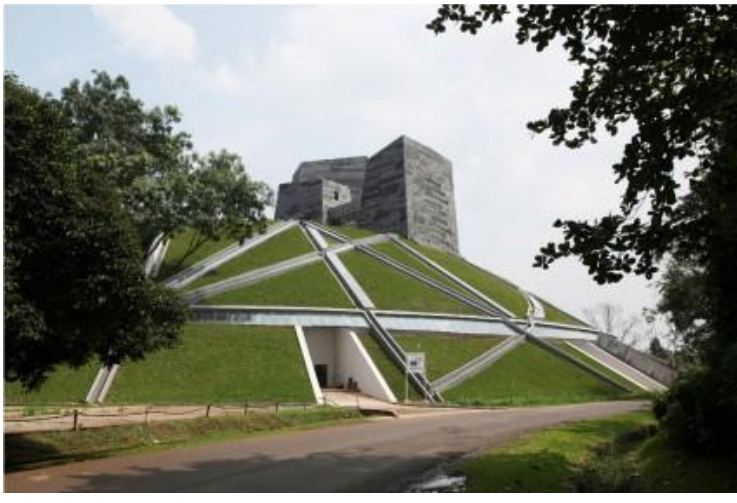

Gambar 7. Bukit buatan sebagai penghijauan pada perpustakaan $U /[11]$

Punggung bukit bangunan ditimbun tanah dan ditanami rerumputan yang berguna sebagai pendingin suhu ruangan yang ada di dalamnya, hingga dapat mereduksi fungsi alat pendingin udara sampai 15\%. Di antara punggung rerumputan itu terdapat jaringanjaringan selokan yang di sampingnya terdapat kaca tebal bening selebar $50 \mathrm{~cm}$. Selokan itu untuk mengalirkan air hujan ke tanah resapan, sedangkan fungsi kaca sebagai system pencahayaan. Untuk memenuhi standar ramah lingkungan, bangunan dilengkapi system pengolahan limbah. Air buangan toilet dapat digunakan untuk menyiram di punggung bangunan dengan diproses terlebih dahulu melalui pengolahan limbah ataus ewage treatment plant (STP).

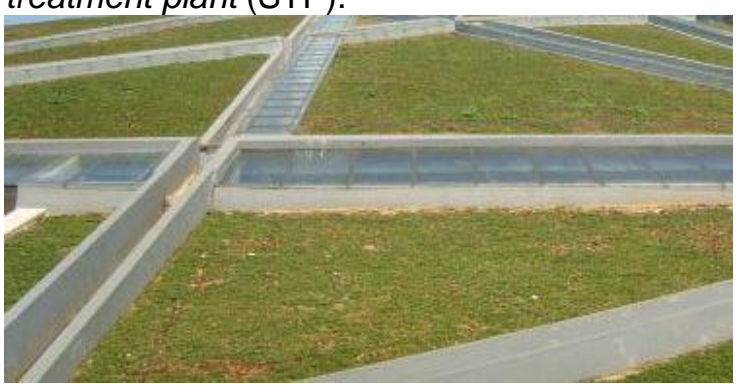

Gambar 8.Saluran air dan skylight padabangunanperpustakaan UI [12]

Interior bangunan perpustakaan $\mathrm{UI}$ didesain terbuka dan menyambung antara satu ruang dan ruang yang lain melalui system void sehingga memaksimalkan penggunaan sirkulasi udara alami. Penggunaan energy matahari diperoleh melalui solar cell yang dipasang di atap bangunan. 


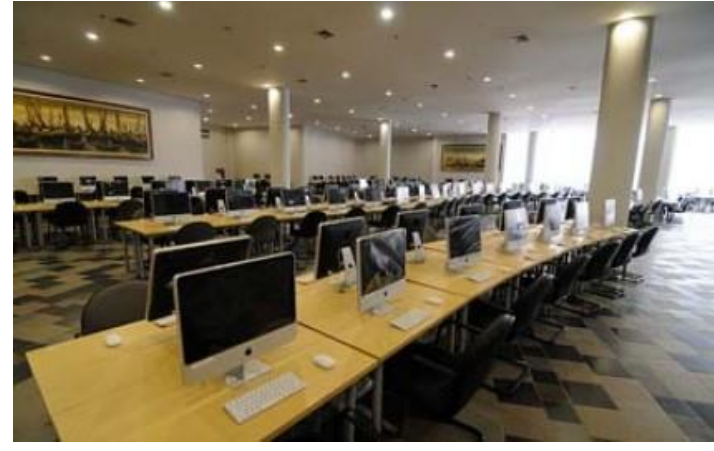

Gambar 9. Interior perpustakaan U/[11]

Bangunan Perpustakaan UI terdiri dari delapan lantai. Lantai dasar berisi pusat kegiatan dan bisnis mahasiswa yang terdiri toko buku, toko cenderamata, ruang internet, serta ruang musik dan TV. Ada juga restoran dan kafe, pusat kebugaran, ruang pertemuan, ruang pameran, dan bank.

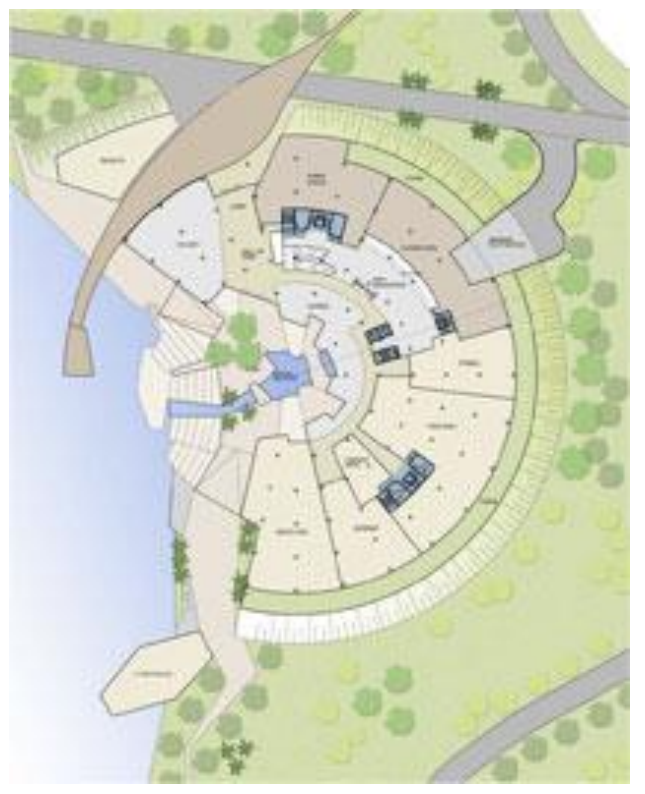

Gambar10. Site plan perpustakaan UI [13]

Lantai $2-6$ dilengkapi fasilitas seperti ruang tamu, ruang pelayanan umum dan koleksi, ruangbaca, ruang teknologi informasi, serta unit pelayanan teknis. Lantai 7 terdapat ruang sidang dan ruang diskusi. Gedung perpustakaan juga dilengkapi plaza dan ruang pertemuan yang menjorok ke danau.

Material bangunan Perpustakaan UI terdiri dari batuan (batu alam andesit pada eksteriornya dan batu paliman palemo pada interiornya) tanpa dicat. Batu andesit merupakan salah satu material thermal mass yang memiliki kemampuan menghambat perpindahan panas masuk ke dalam bangunan. Panas yang diterima akan disimpan dan direradiasikan pada malam hari [14].

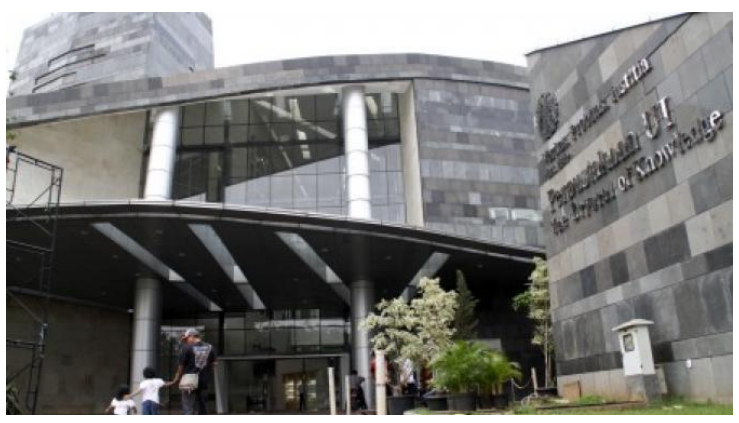

Gambar 11. Material batuandesit pada bangunanperpustakaan U/[12]

Sejumlah pohon besar berusia 30 tahunan berdiameter lebih dari $100 \mathrm{~cm}$ tidak ditebang untuk melengkapi desain ramah lingkungan. Keindahan gedung itu mengeksplorasi secara maksimal keindahan tepi danau yang asri, sejuk, dan, teduh.

Konsep green architecture menekankan peningkatan efisiensi dalam penggunaan air, energi, dan material bangunan, mulai dari desain, pembangunan, hingga pemeliharaan bangunan itu. Desain memperhatikan banyakbukaan untuk memaksimalkan sirkulasi udara dan cahaya alami. Sedikit mungkin menggunakan penerangan lampu dan pengkondisi udara pada siang hari.

\section{KESIMPULAN}

Dari hasil dan pembahasan di atas maka dapat disimpulkan beberapa hal yang berkaitan dengan konsep green building pada bangunan pendidikan di daerah iklim tropis. Pada kedua bangunan yang berfungsi sebagai fasilitas pendidikan yaitu kampus NTU School of Art, Design and Media Singapura dan Gedung Perpustakaan UI Jakarta menggunakan aplikasi green roof. Dalam merancang dan menerapkan green roof tidak bisa dibandingkan dengan atap konvensional, tetapi perbandingannya dengan biaya yang disebabkan oleh polusi air, udara dan lingkungan. Bangunan Perpustakaan UI telah memenuhi kriteria greenship yang dikeluarkan oleh $\mathrm{GBCl}$ khususnya dalam pemilihan material yang menunjang kenyamanan termal.

Sistem berkelanjutan telah menjadi salah satu kebijakan prioritas di negara beriklim tropis. Green roof tidak hanya merupakan upaya untuk menciptakan arsitektur berkelanjutan, tetapi juga dari segi estetika. Green roof merupakan salah satu aplikasi konsep green building yang tepat untuk diaplikasikan pada 
bangunan -bangunan pendidikan yang ada di Jakarta sebagai kota yang memiliki kepadatan bangunan tinggi dan lahan terbuka hijau yang terbatas.

\section{UCAPAN TERIMA KASIH}

Ucapan terimakasih ditujukan kepada Kementrian Ristekdikti sebagai penyandang dana dalam penelitian ini. Dana penelitian ini merupakan hibah Penelitian Dosen Pemula dengan SK Direktur Jenderal Penguatan Riset dan Pengembangan Nomor: 01/E3/KTP/2017 tanggal 6 Januari 2017.

\section{DAFTAR PUSTAKA}

[1] Suryandari, L. dan Danusastro, Y. (2011). Peranan Riset dan Peningkatan Keterampilan Arsitek Lanskap dalam Menghadapi Penerapan Konsep Green Building, Jurnal Lanskap Indonesia Volume 3 Nomor 2.

[2] Salim,E. (2006). Mengarustengahkan Sustainabilitas dalam Kebijakan Pembangunan, Tantangan Ekologis Negara Kepulauan, JurnalLingkungan Volume 1 Nomor 1. (1-4).

[3] Setyaji, PD. (2014). Bangunan Hijau vs Bangunan Non Hijau Studi pada Gedung Utama Kementerian Pekeriaan Umum dan Gedung Juanda II Kementerian Keuangan, Tesis Universitas Gadjah Mada.

[4] GBCl, Greenship, www.gbcindonesia.org , [1 September 2015].

[5] Kanter, R. (2005). Environmental Almanac: Trees, Green Space, and Human Well-being, Toronto.

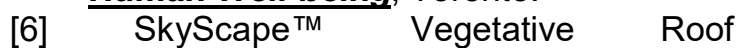
System.http://www.satuatap.com/Produk-Residensial-

Roof\%20Garden.html[20 Desember 2016]

[7] http://agy-aprillyanto.blogspot.co.id/2011/ 04/green-roofs-untuk-masadepan.html[20 Desember 2016]

[8] http://www.greenroofs.com/projects [1 September 2016]

[9] Suseno, G. (2012). Analisis Penggunaan Green Roof Terhadap Kestabilan Suhu Dan Kelembaban Bangunan, Penulisan IImiah Jenjang Setara Sarjana Muda, Teknik Arsitektur Universitas Gunadarma.

[10] http://blogarsitektur.blogspot.com/2010/ 10/solusi-bangunan-ramah lingkungan.htm|[1September 2016] [11]http://www.saveupdata.com/2015/ 12/tempat-baca-asik-di-perpustakaanui.html\#.WGU42PLOuSo [20 Desember 2016]

[12]http://news.okezone.com/read/ 2011/06/24/373/472302/perpus-baru-uiramai-dikunjungi[20 Desember 2016]

[13] http://ajigits.blogspot.co.id/2013/11/ bangunan-ramah-lingkungan-perpusui.htm|[20 Dsember 2016]

[14] Prakoso, NA, dkk.(2014). Kajian Penerapan Material pada Selubung Bangunan yang Mempengaruhi Kenyamanan Termal dan Visual, Jurnal Reka Karsa No.2 Vol. 2 Agustus 2014, Jurnal Online Institut Teknologi Nasional. 